\begin{tabular}{|c|c|}
\hline Jurnal Ayurveda Medistra ISSN. 2656-5609| Volume 2 \\
Issue 2 | 2020 | pages:24-27 \\
Jurnal Ayurveda Medistra Avalaible online at \\
http://Ois.stikesmedistra-indonesia.ac.id//
\end{tabular}

\title{
Pengujian Toksisitas Akut Pada Obat Bahan Alam
}

\author{
Yonathan Tri Atmodjo Reubun ${ }^{1}$, Atut Ruswita Handayani ${ }^{*}$, Marcus Laurentius \\ Yudhi Purwoko ${ }^{3}$, Nursanna Irawaty Sinaga ${ }^{4}$. \\ 1,2,3,4 Program Studi Magister IImu Kefarmasian, Fakultas Farmasi, Universitas \\ Pancasila Jakarta, jonathanreubun90@gmail.com , 08979983814
}

\begin{abstract}
Toxicity tests need to be carried out on a drug product to be marketed. This initial test (screening test) is very important pharmacologically and toxicologically because it will be used for consideration of determining the dosage, the time span of administration and its application. Herbal medicine is a preparation of traditional medicine which until now its use is still needed by people in Indonesia. The toxicity testing method was chosen based on the Organization for Economic Co-operation and Development (OECD) guidelines. This method is a standard method that is recognized by many countries. Europe which is a member of the OECD. The main strengths of this method are the small amount of rodents used and the relatively fast testing time based on $3 R$ principles. in a journal review, LD50 results were obtained in various plants, namely $0.2 \mathrm{~g} / \mathrm{kg} \mathrm{BW,} 2 \mathrm{~g} / \mathrm{kg} \mathrm{BW,} 3.91 \mathrm{~g} / \mathrm{kgBW}, 3.91 \mathrm{~g} / \mathrm{kgBB}, 4.9 \mathrm{~g} / \mathrm{kgBW}, 5 \mathrm{~g} / \mathrm{kg} \mathrm{BW,} 16 \mathrm{~g} / \mathrm{kg} \mathrm{BW}$, and $22.41 \mathrm{~g} / \mathrm{kg} \mathrm{BW}$. The conclusion from this test is the value of the toxic dose of herbal medicine is $>50-300 \mathrm{mg} / \mathrm{kg}$ bw as stated in Annex 2c: OECD / OCE.
\end{abstract}

Keywords: Toxicity test, $L D_{50}$, Jamu.

\begin{abstract}
Abstrak
Uji toksisitas perlu dilakukan pada suatu produk obat yang akan dipasarkan. Uji awal (screening test) ini sangat penting secara farmakologi dan toksikologi karena akan digunakan untuk pertimbangan penentuan dosis, rentang waktu pemberian dan aplikasinya. Jamu merupakan sediaan obat tradisional yang sampai saat ini penggunaannya masih dibutuhkan oleh masyarakat di Indonesia. Metode pengujian toksisitas yang dipilih berdasarkan pedoman Organisation for Economic Co-operation and Development (OECD). Metode ini merupakan metode standar yang diakui oleh banyak negara. Eropa yang merupakan anggota dari OECD. Kelebihan utama metode ini adalah sedikitnya penggunaan hewan pengerat serta waktu ujinya yang relatif cepat dengan berprinsip pada 3R. Pada review jurnal didapatkan beberapa hasil LD 50 pada berbagai tanaman yaitu 0,2g/kg BB, 2g/kg BB, 3,91 g/kgBB, 3,91 g/kgBB, 4.9g/kgBB, 5g/kg $\mathrm{BB}, 16 \mathrm{~g} / \mathrm{kg} \mathrm{BB}$, dan 22,41 g/kg BB. Kesimpulan dari pengujian ini adalah nilai dosis toksik jamu adalah $>50-300 \mathrm{mg} / \mathrm{kg}$ bb seperti disebutkan dalam Annex 2c: OECD/OCE.
\end{abstract}

Kata kunci: Uji Toksisitas, LD50, Jamu. 


\section{PENDAHULUAN}

Pengujian toksisitas merupakan suatu pengujian yang dilakukan dengan tujuan untuk memperkirakan derajat kerusakan yang diakibatkan suatu senyawa terhadap material biologik maupun nonbiologik. Pengujian toksisitas ini biasa dilakukan pada suatu calon produk obat sebagai pemenuhan persyaratan izin edar dan perijinan dari suatu wilayah atau negara. Pengujian toksisitas pada secara umumnya dilakukan guna mengetahui apakah terjadi efek yang tidak dikehendaki pada suatu obat.

Pengujian toksisitas akut dilakukan untuk menentukan efek dari pemberian dosis tunggal suatu senyawa pada hewan. Umumnya direkomendasikan pengujian ini dilakukan terhadap dua jenis hewan (rodensia dan non rodensia). Produk yang diuji diberikan pada hewan coba dengan dosis yang berbeda, kemudian dilakukan pengamatan selama 14 hari. Kematian yang terjadi selama masa pengujian diamati, diuji secara morfologi, biokimia, patologi dan histopatologi dicatat dan diamati. Pengujian akut menghasilkan nilai Lethal dose (LD50). Pada umumnya penentuan lethal dose memerlukan jumlah hewan dalam jumlah besar, yang merupakan hambatan dalam melakukan uji toksisitas. Superjamu merupakan sediaan herbal yang sedang diuji lapang dengan berbagai dosis dan frekwensi pemberian setiap hari dan selang beberapa hari.

The OECD Guidelines for the Testing of Chemicals merupakan standar yang diterima secara internasional untuk menguji keamanan produk, meliputi bahan kimiawi, pestisida, perawatan dan lain-lain. Standar ini selalu ditinjau oleh banyak pakar dari berbagai negara yang termasuk anggota OECD. Metode ini dipilih untuk menguji keamanan produk jamu, sebagai produk yang akan diedarkan untuk memperkirakan dosis toksik. Metode ini dianggap cukup ideal karena menggunakan sedikit hewan coba, mudah aplikasinya dan dapat sekaligus memperkirakan nilai LD 50. Pengujian toksikologi juga dapat digunakan untuk menghitung No Observed Adverse Effect Level (NOAEL) dan bermanfaat untuk uji klinik. ${ }^{1}$ Pandangan moderen yang mulai beralih pada sumber obatobatan natural semakin meningkat. Aspek toksikologi yang masih belum banyak diketahui dari pemakaian bahan pangan maupun obat dikarenakan alasan penggunaan yang turun menurun harus mulai beralih ke penelitian toksikologi karena semakin banyaknya bahan-bahan natural yang dimanfaatkan untuk pengobatan. $^{2}$

\section{METODE PENELITIAN}

Preparasi Hewan Coba. Spesies hewan pengerat yang disukai adalah tikus walaupun spesies hewan pengerat lainnya dapat digunakan. Biasanya tikus betina digunakan. ${ }^{3}$ Ini karena survei literatur dari tes LD50 konvensional menunjukkan bahwa biasanya ada sedikit perbedaan dalam sensitivitas antara jenis kelamin, tetapi dalam kasus-kasus di mana perbedaan diamati, tikus betina umumnya sedikit lebih sensitif. ${ }^{4}$ Namun, jika pengetahuan tentang sifat toksikologis atau toksikokinetik dari bahan kimia yang terkait secara struktural menunjukkan bahwa tikus jantan cenderung lebih sensitif maka jenis kelamin ini harus digunakan. Ketika tes dilakukan pada tikus jantan, pembenaran yang memadai harus diberikan.

Hewan dewasa muda yang sehat dari strain laboratorium yang biasa digunakan harus diperlakukan sebagaimana mestinya, hewan dewasa betina harus nulipara dan tidak hamil. Pada saat dimulainya dosis, setiap hewan harus berusia antara 8 dan 12 minggu dan beratnya harus turun dalam interval dalam $\pm 20 \%$ dari berat awal rata-rata dari setiap hewan yang diberi dosis sebelumnya.

Kandang dan Pakan Hewan. Suhu di ruang hewan percobaan harus pada suhu $22^{\circ} \mathrm{C}\left( \pm 3^{\circ}\right.$ C). Kelembaban setidaknya pada rentang $30 \%$ sampai $70 \%$. Selain itu, sistem pencahayaan harus dapat diatur, dengan waktu 12 jam pada keadaan terang dan 12 jam pada keadaan gelap. Hewan coba ditempatkan secara individual. Untuk pemberian makan, hewan pengerat dapat diberikan air minum yang tidak terbatas.

Persiapan Hewan Coba. Hewan coba dipilih secara acak, ditandai untuk dilakukan identifikasi suatu individu dan dipelihara di kandang mereka setidaknya 5 hari sebelum pemberian dosis untuk memungkinkan aklimatisasi dengan kondisi laboratorium. Seperti dengan desain tes berurutan lainnya, perawatan harus diambil untuk 
memastikan bahwa hewan coba dalam ukuran dan rentang usia yang sesuai dalam keseluruhan prosedur penelitian.

Penggunaan Dosis. Secara umum zat uji harus diberikan dalam volume yang konstan yaitu pada kisaran dosis yang akan diuji dengan memvariasikan konsentrasi sediaan dosis. $\mathrm{Di}$ mana produk akhir cairan atau campuran akan diuji, penggunaan zat uji murni yaitu pada konsentrasi yang konstan, mungkin lebih relevan dengan penilaian risiko selanjutnya dari zat itu sendiri dan merupakan persyaratan dari beberapa otoritas pengawas. Dalam kedua kasus, volume dosis maksimum untuk pemberian tidak boleh dilampaui. Volume maksimum cairan yang dapat diberikan pada satu waktu tergantung pada ukuran hewan uji. Pada tikus, volumenya seharusnya tidak melebihi $1 \mathrm{ml} / 100 \mathrm{~g}$ dari berat badan; namun dalam kasus larutan air, $2 \mathrm{ml} /$ $100 \mathrm{~g}$ berat badan dapat dipertimbangkan. Sehubungan dengan formulasi sediaan takaran, penggunaan larutan / suspensi / emulsi berair direkomendasikan sedapat mungkin, diikuti dalam urutan pilihan oleh larutan / suspensi / emulsi dalam minyak. Untuk sediaan selain air, karakteristik toksikologis sediaan harus diketahui. Dosis harus disiapkan sesaat sebelum pemberian kecuali jika stabilitas persiapan selama periode penggunaannya diketahui dan terbukti dapat diterima.

\section{HASIL DAN PEMBAHASAN}

Pada hasil ini didapatkan beberapa obat bahan alam dimana medapatkan data tentang pengujian toksisitas akut dari beberapa tanaman bahan alam.

\begin{tabular}{|c|c|c|c|}
\hline No & $\begin{array}{l}\text { Nama Bahan } \\
\text { Alam }\end{array}$ & $\mathrm{LD}_{50}$ & Metode \\
\hline 1 & Umbi lles-lles 5 & $2 \mathrm{~g} / \mathrm{kg} \mathrm{BB}$ & $\begin{array}{l}\text { Software AOT } \\
425\end{array}$ \\
\hline 2 & Daun Kelor 6 & $2 \mathrm{~g} / \mathrm{kg} \mathrm{BB}$ & OECD 423 \\
\hline 3 & Daun Waru 7 & $16 \mathrm{~g} / \mathrm{kgBB}$ & OECD 425 \\
\hline 4 & $\begin{array}{l}\text { Daun } \\
\text { Sengkubak }{ }^{8}\end{array}$ & $5 \mathrm{~g} / \mathrm{kg} \mathrm{BB}$ & OECD 425 \\
\hline 5 & Daun Kemangi ${ }^{9}$ & $2 \mathrm{~g} / \mathrm{kg} \mathrm{BB}$ & OECD 420 \\
\hline 6 & Daun Pepolo 10 & $3,91 \mathrm{~g} / \mathrm{kgBB}$ & Konvensional \\
\hline 7 & Daun Kirinyuh ${ }^{11}$ & 14,14g/kg BB & Konvensional \\
\hline 8 & Daun Malaka ${ }^{12}$ & $16 \mathrm{~g} / \mathrm{kg} \mathrm{BB}$ & Konvensional \\
\hline 9 & $\begin{array}{l}\text { Benalu Mangga } \\
13\end{array}$ & $22,41 \mathrm{~g} / \mathrm{kg} \mathrm{BB}$ & Konvensional \\
\hline 10 & Brotowali 14 & $5 \mathrm{~g} / \mathrm{kg} \mathrm{BB}$ & Konvensional \\
\hline 11 & Kubis Bunga ${ }^{15}$ & $15 \mathrm{~g} / \mathrm{kgbb}$ & Konvensional \\
\hline
\end{tabular}

\begin{tabular}{clll}
\hline 12 & $\begin{array}{l}\text { Daun Kamboja } \\
16\end{array}$ & $5.1 \mathrm{~g} / \mathrm{kg} \mathrm{BB}$ & Konvensional \\
13 & Obat Herbal $^{17}$ & $0,2 \mathrm{~g} / \mathrm{kg} \mathrm{BB}$ & OECD 423 \\
14 & Jambu Mede $^{18}$ & $4.9 \mathrm{~g} / \mathrm{kgBB}$ & Konvensional \\
15 & Daun Malaka $^{19}$ & $16 \mathrm{~g} / \mathrm{kg} \mathrm{BB}$ & Konvensional
\end{tabular}

\section{KESIMPULAN}

Pengujian toksisitas akut pada beberapa jurnal diketahui masih dengan menggunakan beberapa metode seperti OECD maupun konvensional. Pengujian ini bertujuan untuk menentukan efek dari pemberian dosis tunggal suatu senyawa pada hewan seperti tikus atau mencit yang diukur selama 14 hari. Pengujian toksisita akut ini juga menghasilkan nilai Lethal dose (LD50). Pada umumnya penentuan lethal dose memerlukan jumlah hewan dalam jumlah besar, yang merupakan hambatan dalam melakukan uji toksisitas. Diketahui dari beberapa jurnal yang kami dapatkan diketahui bahwa LD $_{50}$ dari beberapa tanaman mempunyai nilai yang berbeda yaitu $0,2 \mathrm{~g} / \mathrm{kg}$ BB, $2 \mathrm{~g} / \mathrm{kg}$ BB, 3,91 $\mathrm{g} / \mathrm{kgBB}, 3,91 \mathrm{~g} / \mathrm{kgBB}, 4.9 \mathrm{~g} / \mathrm{kgBB}, 5 \mathrm{~g} / \mathrm{kg}$ BB, $16 \mathrm{~g} / \mathrm{kg} \mathrm{BB}$, dan 22,41 g/kg BB.

\section{UCAPAN TERIMA KASIH}

Tim penulis mengucapkan terima kasih kepada Prof. Dr. Syamsudin. M.Biomed., Apt. atas perhatian dan arahannya dalam pembuatan jurnal ini.

\section{DAFTAR PUSTAKA}

1. Setzer, R.W. and Kimmel, C.,A. (2003) Use of NOAEL, benchmark dose, and other models for human risk assessment of hormonally active substances. Pure Appl Chem. 75:2151-8.

2. Lee, J.E., Kim, H.J., Choi E.K., Chai, H.Y., Yun, Y.W., Kim, D.J., Nam, S.Y., Lee, B.J. Ahn, B.W., Kang, H.G., and Kim, Y.B. (2003) Fourweek repeateddose toxicity study on Pinellia Extract. Korean J. Lab. Anim. Sci. 19:127-141.

3. OECD (2000). Guidance Document on Acute Oral Toxicity . Environmental Health and Safety Monograph Series on Testing and Assessment No 24.

4. Lipnick R.L., Cotruvo J.A., Hill R.N., Bruce R.D., Stitzel K.A., Walker A.P., Chu I., Goddard M., Segal L., Springer 
J.A., and Myers R.C. (1995). Comparison of the Up-and-Down, Conventional LD50 and Fixed Dose Acute Toxicity Procedures. Fd. Chem. Toxicol., 33, 223-231.

5. Makiyah, Arfatul. Uji Toksisitas Akut yang Diukur dengan Penentuan LD50 Ekstrak Etanol Umbi lles-iles (Amorphophallus variabilis Bl.) pada Tikus Putih Strain Wistar. Sukabumi, 2017. 145-155

6. Moodley, Indres. Acute toxicity of Moringa oleifera leaf powder in rats. Durban, Journal of Medicinal Plants Studies, 2017. 180-185

7. Oktavia, Sri. uji toksisitas akut ekstrak daun waru (Hibiscus tiliaceus I.) pada mencit putih jantan. Padang. Jurnal Farmasi Higea. 2018. 41-48.

8. Pamuji, Riska. Uji Toksisitas Akut Ekstrak Etanol Daun Sengkubak (Pycnarrhena Cauliflora Diels) Terhadap Tikus Betina Galur Wistar Dengan Metode OECD 425. Pontianak. Naskah Publikasi. 2015.

9. Abrori, Cholis. Uji Toksisitas Akut Ekstrak Etanol Daun Kemangi (Ocimumsanctum) Diukur dari Nilai LD50 dan Histopatologi Ginjal. Jember. Journal of Agromedicine and Medical Sciences. 2019. 13-19

10. Ihwan. Uji Toksisitas Akut Dan Letal Dose (LD50) Ekstrak Etanol Daun Pepolo (Bischofia javanica Blume) Pada Mencit Putih (Mus musculus). Palu. Natural Science: Journal of Science and Technology. 2018. 110-116

11. Jumain. Uji Toksisitas Akut dan LD50 Ekstrak Etanol Daun Kirinyuh (Euphatorium odoratum Linn) Pada Mencit (Mus musculus). Makassar.
Media Farmasi Vol. XIV. No. 1. 2018. 6571.

12. Armansyah, T. Uji Toksisitas Akut Ekstrak Etanol Daun Malaka (Phyllanthus emblica) terhadap mencit (Mus musculus). Banda Aceh. Jurnal Kedokteran Hewan. 2016. 192-194.

13. L, Diantika. Uji Toksisitas Akut Ekstrak Etanol Benalu Mangga (Dendrophthoe petandra) Terhadap Mencit Swiss Webster. Sumedang. IJPST. 53-65

14. Triyono, A. Uji Toksisitas Akut Dan Subkronik Ekstrak Brotowali (Tinospora Crispa (L) Miers). Karanganyar. 130-135.

15. Setiasih, Imas Siti. Uji Toksisitas Kubis Bunga Diolah Minimal (KBDM) Hasil Ozonasi. Bandung. Jurnal Penelitian Pangan Volume 1.1. 2016. 22-26.

16. Warsito, Rangga. Uji Toksisitas Akut Ekstrak Daun Kamboja (Plumiera rubra L.) pada Ikan Nila Merah (Oreochromis niloticus). Medan.

17. Sasmito, Wiku Adi. Pengujian Toksisitas Akut Obat Herbal Pada Mencit Berdasarkan Organization for Economic Co-operation and Development (OECD). Yogyakarta. JSV 33. 2015. 234-239.

18. Noncim Faridha Yenny. Uji Toksisitas Akut Ekstrak Etanol Klika Jambu Mede (Anacardium Occidentale L.) Pada Mencit Jantan (Mus Musculus). Makassar. Jf Fik Uinam Vol.2. 2014. 6268

19. T. Armansyah. Uji Toksisitas Akut Ekstrak Etanol Daun Malaka (Phyllantus Emblica) Terhadap Mencit (Mus Musculus). Banda Aceh. Jurnal Kedokteran Hewan. 2016. 192-194. 